Physical Geography; Cartography; Geographic Information Systems \& Spatial Planing

\title{
THE INFLUENCE OF THE LARGEST TRIBUTARIES OF VARDAR RIVER FOR WATER POLLUTION WITH SOME HEAVY METALS
}

DOI: http://dx.doi.org/10.18509/GBP.2016.12

UDC: 504.5:556.524(497.7)

\author{
Dr. Kole Pavlov \\ Josip Broz Tito High School, Skopje, Republic of Macedonia
}

\begin{abstract}
The Vardar River is the main recipient of surface flowing water, urban and industrial wastewater in the country with a length of $301 \mathrm{~km}$ and a catchment area of $20535 \mathrm{~km}^{2}$ or $80 \%$ of the national territory. In the Tikves Basin, Vardar River receives its major tributaries: the Bregalnica River from left side and Crna Reka from the right side. Their input undoubtedly reflects on the water quality of the recipient. This influence is evident through the annual monitoring regime in the concentration of some indicators such as heavy metals in the Vardar River which demonstrate some certain swag in the water quality of the recipient, before and after the entry of its largest tributaries.
\end{abstract}

Key words: Vardar River, tributary, water pollution, heavy metals, etc.

\section{INTRODUCTION}

Vardar River Basin covers $80 \%$ of the territory of the Republic Macedonia [1]. It is also the largest recipient of industrial and urban waste water in the country. Many factors have changed the water quality of the river Vardar along the course, indirect, bringing pollutants through its numerous tributaries. For these reasons, spontaneously arose the need to study the water quality of the river Vardar, exactly around the stretch where it receives its largest tributary in the Tikves Basin, Bregalnica from the left side and Crna Reka on the right (fig. 1). Thus in this paper were studied the waters of river Vardar in Tikves Basin with the tributaries Bregalnica and Crna Reka. The waters of Vardar were monitored from two measuring points: before and after the entry of its largest tributaries, ie with Nogaevci (point 1, fig. 1) and near Demir Kapija (point 2, fig. 1). The assessment of water quality of Vardar was based on 8 heavy metals as a criterion for quality. Heavy metals are among the most common environmental pollutants and their occurrence in water and biota indicates the presence of natural or anthropogenic sources [2]. The purpose of the paper is to assess the impact of the largest tributaries of the Vardar about the burden of the recipient with heavy metals. To achieve the goals and adopting the correct conclusions, while the load, the rivers Bregalnica and Crna Reka were checked from heavy metals before the inflow into the river Vardar (point 3, 4, fig. 1).

\section{STUDY AREA}

Vardar River with its middle, reaches through Tikves Basin $\left(2060 \mathrm{~km}^{2}\right)$ extends a length of $62.7 \mathrm{~km} \mathrm{[3].} \mathrm{On} \mathrm{that} \mathrm{point} \mathrm{the} \mathrm{river} \mathrm{Vardar} \mathrm{receives} \mathrm{its} \mathrm{major} \mathrm{tributaries.} \mathrm{Bregalnica}$ $(225 \mathrm{~km})$ is the largest tributary from the left side and flows near the village Vinichani at an altitude of 131 meters (fig. 1). Crna Reka $(207 \mathrm{~km})$ is the largest right tributary of the Vardar River which flows near the site of Stobi at 129 meters altitude. 


\section{METHODS AND MATERIALS}

In order to objectively detect the pollution of the water in Vardar River with heavy metals in Tikves Basin, which receives the largest tributaries of the left and right, purposefully were selected two monitoring points at a frequency of analyzed samples once a month in the period 2001-2010 year. First, upper, monitoring point near the village Nogaevci was determined in order to assess the state of heavy metals in the river Vardar before the input of water from its major tributaries. Lower monitoring point at Demir Kapija is chosen in order to estimate the changes from which suffered the water of Vardar in the Tikves Basin influenced by imported water from major tributaries. The burden of heavy metals was monitored simultaneously with the same frequency in Bregalnica and Crna Reka in Vardar. Sampling is implemented according to the ISO 5667. Water samples were collected and analyzed in the laboratory of the Hydrometeorological Service. Heavy metals concentration of $\mathrm{Fe}, \mathrm{Mn}, \mathrm{Pb}, \mathrm{Cd}, \mathrm{Zn}, \mathrm{Cr}, \mathrm{Ni}, \mathrm{Cu}$ were determined by atomic absorption spectrometry using Varian 220 by graphite furnace and flame technique. As methods for detemination of these parameters are used methods recommended by Standard Methods for the Examination of Water and Wastewater APHA, EPA, and EN/ISO methods.

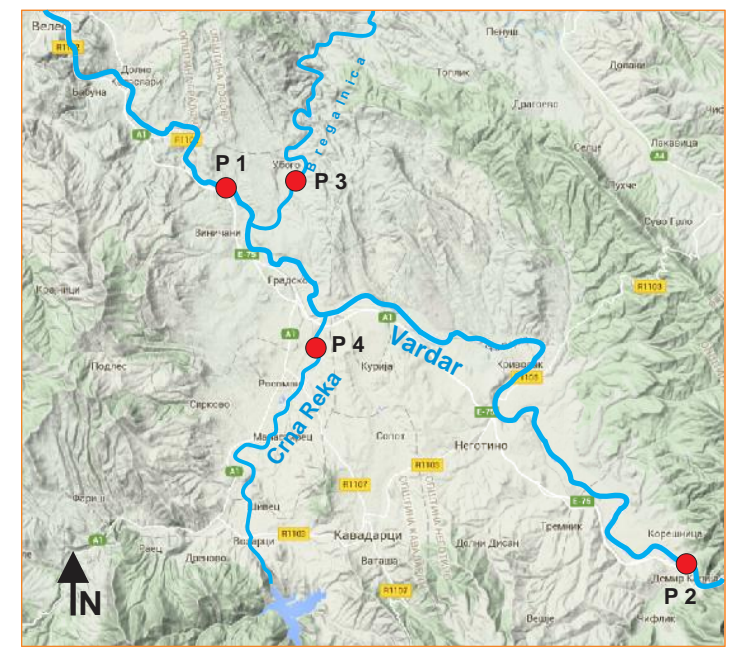

Figure 1. A part of the catchment area of Vardar River and its tributaries in the Tikves Basin

Table 1. Concentrations of heavy metals in the water of river Vardar near the village. Nogaevci $(\mu \mathrm{g} / \mathrm{l})$

\begin{tabular}{|c|c|c|c|c|c|c|c|c|c|c|c|c|c|}
\hline \multirow[t]{2}{*}{ Element } & \multicolumn{12}{|c|}{ MONTH } & Average \\
\hline & I & II & III & IV & $\mathbf{V}$ & VI & VII & VIII & IX & $\mathbf{X}$ & XI & XII & $\begin{array}{l}(2001- \\
2010)\end{array}$ \\
\hline $\mathrm{Fe}$ & 78,0 & 112,0 & 98,0 & 124,0 & 100,0 & 40,0 & 61,0 & 46,0 & 81,0 & 70,0 & 45,0 & 156,0 & 84,25 \\
\hline Mn & 31,30 & 33,80 & 29,60 & 50,80 & 16,80 & 14,80 & 14,60 & 12,10 & 22,30 & 30,30 & 34,10 & 30,00 & 24,10 \\
\hline $\mathbf{P b}$ & 0,60 & 1,10 & 0,90 & 1,10 & 0,70 & 0,90 & 0,70 & 1,80 & 0,80 & 0,70 & 0,90 & 0,80 & 0,92 \\
\hline Zn & 32,30 & 20,50 & 13,80 & 13,50 & 5,70 & 7,30 & 13,40 & 122,0 & 12,30 & 17,60 & 32,80 & 38,50 & 27,50 \\
\hline Cd & 0,93 & 0,65 & 1,25 & 0,23 & 0,1 & 0,25 & 0,25 & 0,27 & 0,2 & 0,33 & 0,21 & 0,67 & 0,4 \\
\hline $\mathrm{Cr}$ & 1,30 & 2,20 & 1,40 & 0,80 & 1,10 & 1,70 & 1,40 & 0,90 & 0,60 & 1,00 & 1,10 & 1,00 & 1,20 \\
\hline $\mathrm{Ni}$ & 1,30 & 1,90 & 2,20 & 2,10 & 1,40 & 0,90 & 0,80 & 1,20 & 0,60 & 1,60 & 1,50 & 0,40 & 1,33 \\
\hline $\mathbf{C u}$ & 2,90 & 4,00 & 4,30 & 3,30 & 3,10 & 2,90 & 3,10 & 1,50 & 3,70 & 2,60 & 2,20 & 3,30 & 3,10 \\
\hline
\end{tabular}

Table 2. Concentrations of heavy metals in the water of the river Vardar at Demir Kapija ( $\mu \mathrm{g} / \mathrm{l})$

\begin{tabular}{|c|c|c|c|c|c|c|c|c|c|c|c|c|c|}
\hline \multirow[t]{2}{*}{ Element } & \multicolumn{12}{|c|}{ MONTH } & Average \\
\hline & I & II & III & IV & $\mathbf{V}$ & VI & VII & VIII & IX & $\mathbf{X}$ & XI & XII & $\begin{array}{l}(2001- \\
2010)\end{array}$ \\
\hline $\mathbf{F e}$ & 49.2 & 56.5 & 39.7 & 107,0 & 43.8 & 31,7 & 34.8 & 36.4 & 36,0 & 29.0 & 47.4 & 106,0 & 51,50 \\
\hline Mn & 26,80 & 26,00 & 23,40 & 30,40 & 5,90 & 7,50 & 10,50 & 6,20 & 10,90 & 17,40 & 19,60 & 9,70 & 16,20 \\
\hline $\mathbf{P b}$ & 0,70 & 0,90 & 0,70 & 0,80 & 1,10 & 1,00 & 1,00 & 1,80 & 1,30 & 1,10 & 1,60 & 0,90 & 1,10 \\
\hline $\mathbf{Z n}$ & 1,10 & 1,40 & 1,70 & 2,40 & 1,70 & 1,40 & 0,90 & 1,10 & 0,50 & 0,90 & 1,10 & 1,20 & 1,30 \\
\hline
\end{tabular}


Physical Geography; Cartography; Geographic Information Systems \& Spatial Planing

\begin{tabular}{|l|l|l|l|l|l|l|l|l|l|l|l|l|l|}
\hline $\mathbf{C d}$ & 0,15 & 0,38 & 0,27 & 0,09 & 1,54 & 0,16 & 0,21 & 0,17 & 0,12 & 0,13 & 0,28 & 0,33 & $\mathbf{0 , 3 2}$ \\
\hline $\mathbf{C r}$ & 0,60 & 1,00 & 0,60 & 0,70 & 0,60 & 0,60 & 0,70 & 0,80 & 0,50 & 0,50 & 1,00 & 1,00 & $\mathbf{0 , 7 0}$ \\
\hline $\mathbf{N i}$ & 1,10 & 1,40 & 1,70 & 2,40 & 1,70 & 1,40 & 0,90 & 1,10 & 0,50 & 0,90 & 1,10 & 1,20 & $\mathbf{1 , 3 0}$ \\
\hline $\mathbf{C u}$ & 2,40 & 3,00 & 1,80 & 3,40 & 3,30 & 3,30 & 2,20 & 2,00 & 2,90 & 2,20 & 3,60 & 1,90 & $\mathbf{2 , 6 0}$ \\
\hline
\end{tabular}

Table 3. Concentrations of heavy metals in the water of the river Bregalnica, before confluence $(\mu \mathrm{g} / \mathrm{l})$

\begin{tabular}{|c|c|c|c|c|c|c|c|c|c|c|c|c|c|}
\hline \multirow[t]{2}{*}{ Element } & \multicolumn{12}{|c|}{ MONTH } & Average \\
\hline & I & II & III & IV & $\mathbf{V}$ & VI & VII & VIII & IX & $\mathbf{X}$ & XI & XII & $\begin{array}{l}\text { (2001- } \\
2010)\end{array}$ \\
\hline $\mathrm{Fe}$ & 46.0 & 58.4 & 48.0 & 68,00 & 27.0 & 32.4 & 30,10 & 15,60 & 44,90 & 39.1 & 70.1 & 127,0 & 50,50 \\
\hline Mn & 14,00 & 35,00 & 24,80 & 31,70 & 8,30 & 19,40 & 33,00 & 17,70 & 31,30 & 18,10 & 23,80 & 84,50 & 28,50 \\
\hline $\mathbf{P b}$ & 0,00 & 1,20 & 0,90 & 1,40 & 3,40 & 1,60 & 1,00 & 1,90 & 1,20 & 0,70 & 2,00 & 0,10 & 1,30 \\
\hline $\mathbf{Z n}$ & 7,50 & 4,90 & 4,20 & 6,20 & 2,70 & 3,30 & 11,90 & 6,60 & 3,70 & 20,60 & 8,00 & 0,80 & 6,70 \\
\hline Cd & 0.00 & 0.15 & 0.07 & 0.05 & 0.12 & 0.10 & 0.56 & 0.14 & 0.10 & 0.07 & 0.18 & 0.00 & 0.13 \\
\hline $\mathrm{Cr}$ & 0,50 & 0,80 & 0,70 & 1,00 & 0,40 & 0,70 & 0,60 & 0,80 & 0,80 & 0,90 & 0,70 & 0,70 & 0,70 \\
\hline $\mathrm{Ni}$ & 0,60 & 1,70 & 1,90 & 1,40 & 2,30 & 1,40 & 0,80 & 1,30 & 0,60 & 0,90 & 1,20 & 0,40 & 1,20 \\
\hline $\mathrm{Cu}$ & 2,00 & 3,10 & 3,50 & 3,90 & 3,90 & 2,40 & 1,70 & 1,70 & 1,90 & 1,20 & 2,10 & 1,50 & 2,40 \\
\hline
\end{tabular}

Table 4. Concentrations of heavy metals in the water of Crna Reka, before confluence $(\mu \mathrm{g} / \mathrm{l})$

\begin{tabular}{|c|c|c|c|c|c|c|c|c|c|c|c|c|c|}
\hline \multirow{2}{*}{ Element } & \multicolumn{12}{|c|}{ MONTH } & \multirow{2}{*}{$\begin{array}{c}\text { Average } \\
(2001- \\
2010)\end{array}$} \\
\hline & I & II & III & IV & $\mathbf{V}$ & VI & VII & VIII & IX & $\mathbf{X}$ & XI & XII & \\
\hline $\mathbf{F e}$ & 55,0 & 26,0 & 106,0 & 120,0 & 45,9 & 44,6 & 49,6 & 29,6 & 33,1 & 21,5 & 32.3 & 33,3 & 49,8 \\
\hline Mn & 40,00 & 29,60 & 22,30 & 24,30 & 14,40 & 17,80 & 8,00 & 6,80 & 17,80 & 22,30 & 21,70 & 15,30 & 18,30 \\
\hline $\mathbf{P b}$ & 1,00 & 1,00 & 0,80 & 1,20 & 0,70 & 1,30 & 0,50 & 1,10 & 0,80 & 0,80 & 0,50 & 1,50 & 0,90 \\
\hline $\mathbf{Z n}$ & 11,70 & 5,00 & 5,70 & 12,10 & 24,10 & 4,20 & 10,10 & 10,40 & 3,00 & 15,30 & 7,70 & 5,80 & 9,60 \\
\hline Cd & 0.19 & 0.04 & 0.14 & 0.06 & 0.10 & 0.13 & 0.13 & 0.08 & 0.08 & 0.10 & 0.09 & 0.07 & 0.10 \\
\hline $\mathrm{Cr}$ & 1,00 & 1,00 & 0,80 & 1,20 & 0,70 & 1,30 & 0,50 & 1,10 & 0,80 & 0,80 & 0,50 & 1,50 & 0,90 \\
\hline $\mathbf{N i}$ & 1,80 & 2,50 & 1,90 & 2,10 & 1,90 & 1,60 & 0,70 & 0,70 & 1,00 & 1,20 & 1,00 & 1,80 & 1,50 \\
\hline $\mathbf{C u}$ & 2,70 & 2,90 & 3,20 & 3,70 & 3,20 & 3,20 & 2,20 & 2,50 & 2,20 & 1,90 & 2,70 & 3,00 & 2,80 \\
\hline
\end{tabular}

Figure 2. Annual regime of the concentration of heavy metals in the Vardar River near Nogaevci $(\mu \mathrm{g} / 1)$

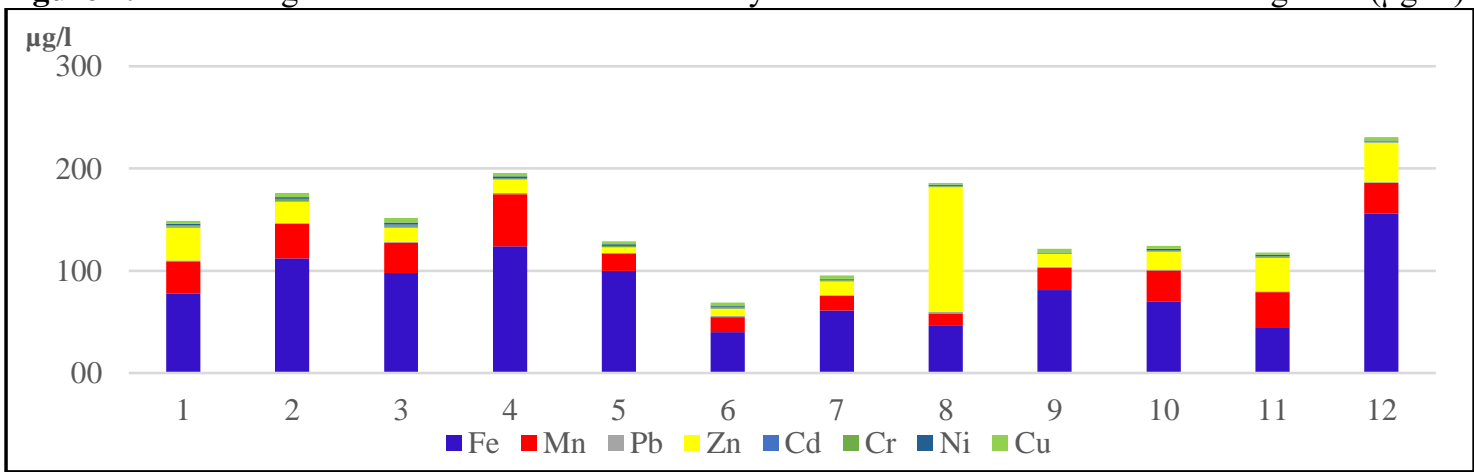

Figure 3. Annual regime of the concentration of heavy metals in Vardar River at Demir Kapija $(\mu \mathrm{g} / 1)$

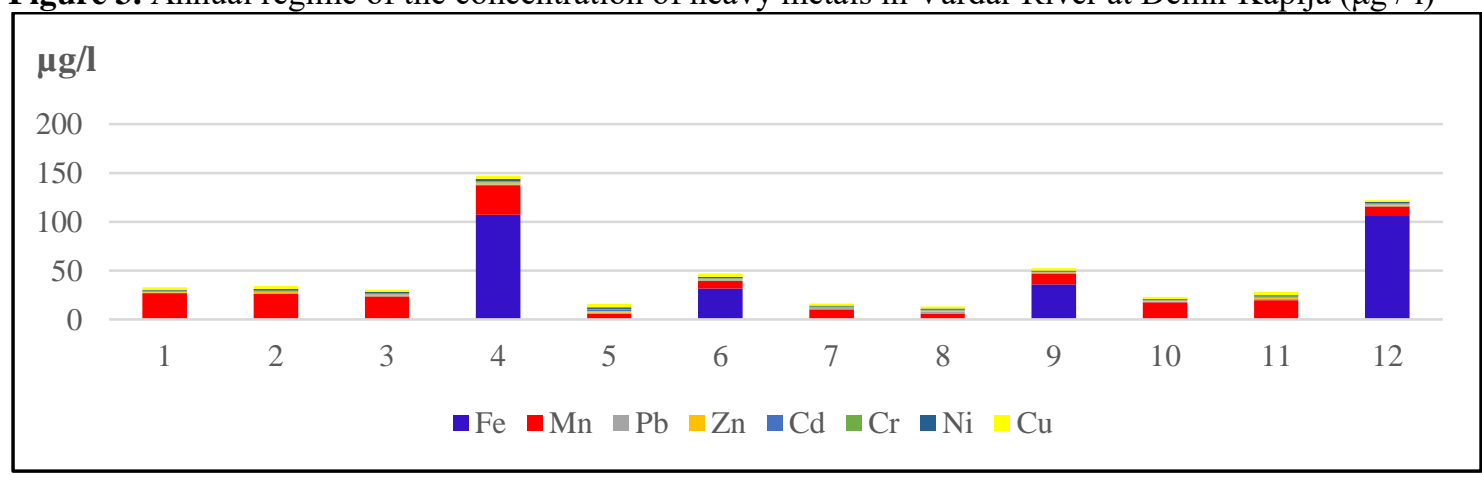


Figure 4. Annual regime of the concentration of heavy metals in Bregalnica River, before estuary $(\mu \mathrm{g} / 1)$

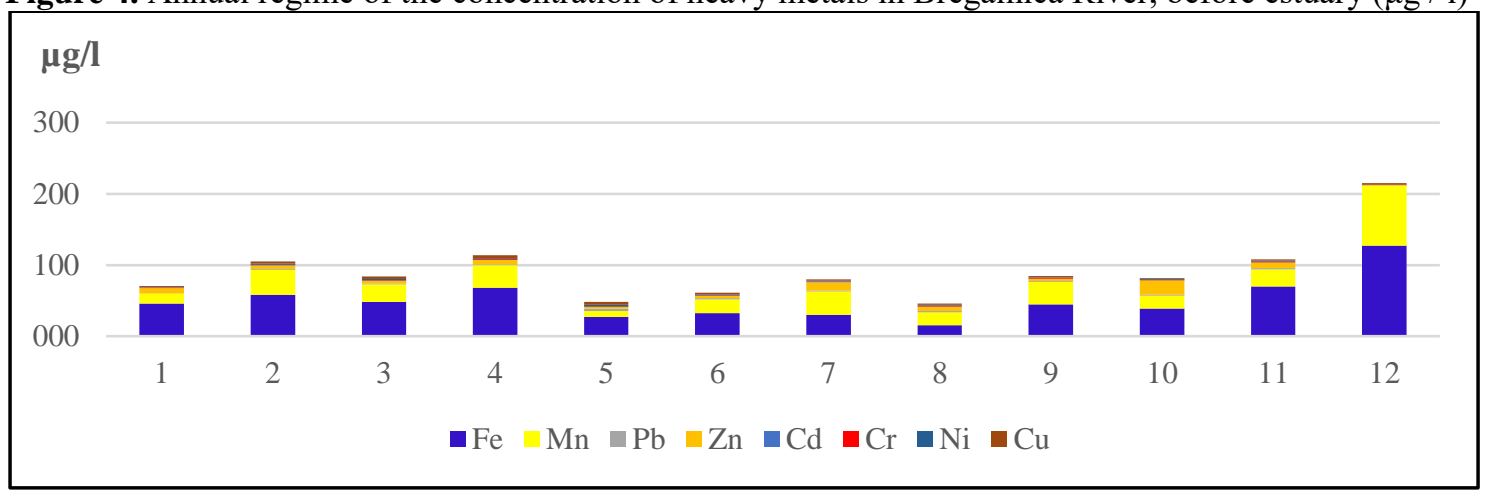

Figure 5. Annual regime of the concentration of heavy metals in Crna Reka, before estuary ( $\mu \mathrm{g} / \mathrm{l})$

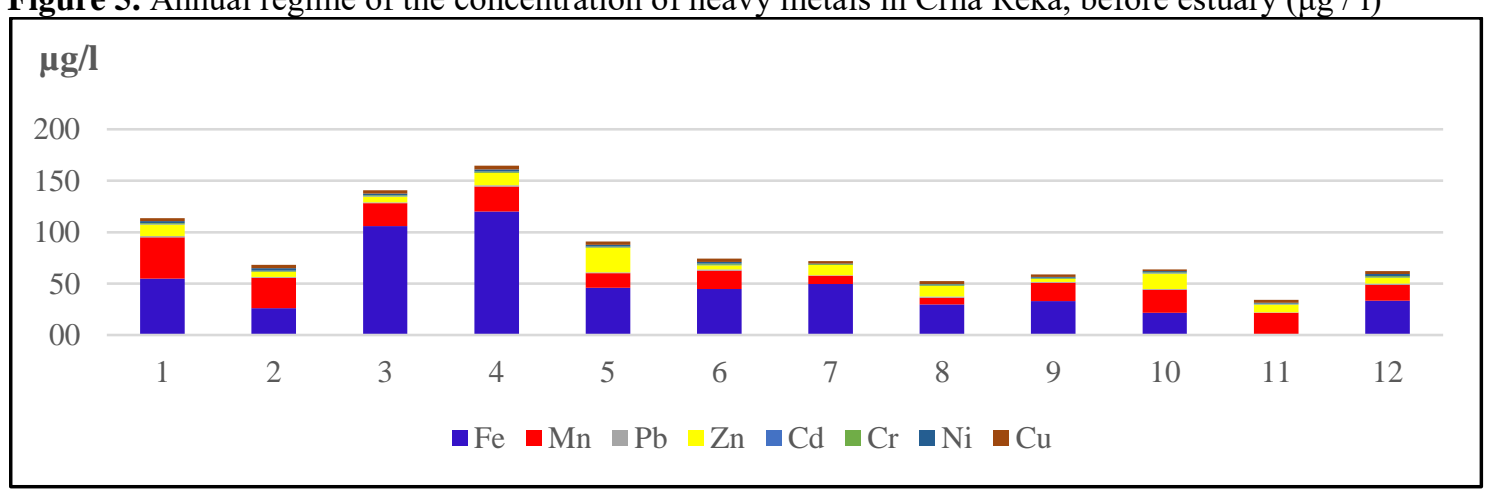

\section{RESULTS AND DISCUSSION}

The analysis of data on the amount of iron as an indicator in major tributaries of the Vardar in Tikves Basin explicitly suggest the conclusion that they do not perform pressures on the recipient. The annual and seasonal concentrations of iron in the period (2001-2010) in Bregalnica River before confluence (50,5 $\mu \mathrm{g} / \mathrm{l})$ and Crna Reka $(49,8 \mu \mathrm{g} / \mathrm{l})$ is maintained in a class I-II (tab. 3, 4). Annually, the values of iron in Bregalnica and Crna Reka is even lower than theVardar of the two measuring points. This indicates that these flows do not pollute the Vardar iron considering that concentrations of this toxic metal is reduced downstream (tab. 1, 2; fig. 2, 3) of $84 \mu \mathrm{g} / 1$ (point 1) to $515 \mu \mathrm{g} / 1$ (point 2). Manganese in water naturally derived mostly from dissolving shales and sandstones, and throws the man through metallurgical activities. In irrigation water must not exceed a concentration of $0,2 \mu \mathrm{g} / 1$ [4]. The average value of $24.1 \mu \mathrm{g} / \mathrm{l} \mathrm{Mn}$ in the waters of river Vardar at Nogaevci (point 1) in the investigated period, matched with the norms for class I-II quality. The defined amount of manganese in the waters of Vardar at Nogaevci cannot exempt anthropogenic factor as agent for its input as show average values for the month of April corresponding to class III-IV. The general conclusions that impose strongly encouraged to apply tables and graphs (tab. 1, 2; fig. 2, 3) the finding of manganese in the largest tributaries of the Vardar in the direction that best one among them is the Crna Reka in Palikura (point 4), and most burdened is Bregalnica and the place Ubogo (point 4). Their concentrations in the ten-year period is in constant parity for class I-II, and do not significantly influence the main recipient of Tikves region which applies to the area of pollutants. The values of manganese in Bregalnica's Ubogo is the highest, but within the class I-II. Lead is a heavy metal that in the rivers can be deposited by mining and 
industrial waste from factories, military vehicles, batteries, batteries and more. Irrigation water in its concentration, long-term, should not exceed 5,0 $\mu \mathrm{g} / 1$ [5]. The average value of $0,9 \mu \mathrm{g} / 1 \mathrm{~Pb}$ in the river Vardar at the measuring station Nogaevci (point 1) and $1,1 \mu \mathrm{g} / 1$ in Demir Kapija (point 2) in the investigated period, parry the desired norms of class I-II quality. With known monthly fluctuations of lead may be due to natural processes without apparent human influence, such as changes in water temperature, $\mathrm{pH}$ value and water hardness. The general review of the above charts and graph (tab. 1, 2; fig. 2, 3) are aimed at detecting the very faint but still evident deterioration of age as an indicator according to lead through Tikves region. The reason for this trend is visible in data Bregalnica (tab. 3; fig. 4) Its waters loaded with lead from the upper sections of the measuring point Ubogo (point 3) is satisfactory (class I-II), but highest among examined watercourses $(1,3 \mu \mathrm{g} / \mathrm{l})$. It may be noted that it is likely that the minimum source, measured in desirable, worsens the quality of Vardar in this section, and the impact of the Crna Reka $(0,9 \mu \mathrm{g} / \mathrm{l})$ is less (tab. 4, fig. 5). Zinc is relatively non-toxic to terrestrial organisms. It is acutely and chronically toxic to aquatic organisms, particularly fish. Zinc toxicity decreases with increasing hardness, increases with increasing temperature, and increases with decreasing dissolved oxygen [6]. If it is known that in unpolluted waters its concentration does not exceed $5 \mu \mathrm{g} / 1$, then it is visible the impact of anthropogenic factor on the water of the river Vardar. There is no doubt that the waters of Vardar at Nogaevci (point 1), according to the average monthly and annual concentrations of zinc during the period 2001-2010 are the norm for class I-II. Striking bounce in the series was recorded in 2003 when the quality fit for class III-IV. Three times lower amounts of zinc in the waters of Vardar at Demir Kapija (point 2), strikingly reflect the trend of some processes that affects the water flow along the section in the Tikves Valley (tab. 1, 2, fig. 2, 3). The impact of Bregalnica (point 3) on pollution of Vardar is evident in the investigated period due to apparent lower value $(6,70 \mu \mathrm{g} 1)$ of the measuring point in Nogaevci. Quite slightly higher values of the Crna Reka in Palikura $(9,60 \mu \mathrm{g} / \mathrm{l})$, but still within the class I-II. By the rivers Bregalnica and Crna Reka excluded as factors of pollution of Vardar with zinc as pollutants. Cadmium is a toxic metal that in nature is very rare. In some rivers in R. Macedonia is naturally present and originating in certain Paleozoic and Mesozoic rocks [7, 8]. A comparison of values in tabular and graphical data to its average movement in the waters of Vardar of the input point in Tikves (2001-2010) in Nogaevci (point 1), suggests that in terms of the criteria they match class III-IV and probably the concentrations in this area are of natural origin [7, 8]. The tendency of certain decrease in the concentration of cadmium in the waters of Vardar through Tikves is evident, but the quality Class III-IV in all seasons, ever present, the two measuring points (point 1, point 2). Once again in the case of cadmium manifested his seasonal variation which coincides with elevated fortress and $\mathrm{pH}$ value in the warmer months when it is reduced and vice versa. According to the above image data, the least polluted is Crna Reka (point 4) and in the investigated period shows limits of cadmium between class I-II and III-IV with individual monthly indexes for class III-IV. Quite slightly higher are the concentrations in Bregalnica's Ubogo (point 3 ) but they are not pronounced as an impact on the recipients who posses certainly a greater load with cadmium from its largest tributaries (tab. 1, 2, 3, 4; fig. 2, 3, 4, 5). Chromium is a heavy metal naturally present in chromite ore $\left(\mathrm{FeCr}_{2} \mathrm{O}_{4}\right)$. A comparison of the limit values for the hexavalent chrome to its average movement in the waters of the Vardar (point 1) Nogaevci (2001-2010) clearly leads to conclusion that in terms of this criterion $(1,20 \mu \mathrm{g} / \mathrm{l})$ correspond to those of class I-II (tab. 1; fig. 2.). Its high-quality water is permanently retained in all possible indentured analyzed samples indicating the 
absence of anthropogenic factor in the analyzed period. Average monthly and annual values of concentration of hexavalent chromium in the water of Vardar at Demir Kapija (point 2) are smaller than those of the measuring point in Nogaevci and correspond to quality class I-II (tab. 2; fig. 3). The slight reduction in the concentration of chromium annually station in Demir Kapija in respect of the first monitoring point Nogaevci shows minimal improvement of water quality of Vardar in this sectionIn addition to the above settings are the graphical data (tab 3, 4; fig. 4, 5) on rivers Bregalnica and Crna Reka, which in general (Bregalnica) or quite minimal (Crna Reka) influence the main recipient with the input of hexavalent chromium on the move in the Tikves Basin. Existing low concentrations of chromium in the waters of Vardar in Tikves Basin, of anthropogenic origin and mainly come from upstream regions through which passes the water flow. The concentration of nickel in the Vardar River in Tikves in examined period consistently maintained low levels of both measuring points $(1,33 \mu \mathrm{g} / \mathrm{l}$ and $1,30 \mu \mathrm{g} / \mathrm{l})$ which corresponds to quality class I-II (tab. 1, 2; fig. 2, 3) excluding the anthropogenic presence. Symbolically the reduced value of the nickel measuring station Demir Kapija is in sufficient premise that in terms of this indicator in the region comes to improving water quality. The elaboration of the values of nickel in the river Bregalnica (point 3) in Ubogo (2001-2010) undoubtedly indicates that between four measurement points, it is the least burdened with heavy metal test. It constantly keeps in concentrations class I-II. The lower average value of measuring point Ubogo than Demir Kapija (point 2) of the river Vardar largely excluded during Bregalnica pollution as a factor of age with nickel. The average value of measuring point Palikura (point 4), which is the highest softer bigger analyzed rivers $(1,50 \mu \mathrm{g} / \mathrm{l})$. But water quality however without excesses constantly keeps in class I-II. Copper as a heavy metal in aquatic ecosystems comes from some minerals (limestone, sandstone), mining and metallurgical activities and excessive use of fungicides in agriculture [9]. The average value of the copper in the river Vardar at Nogaevci measuring point (point 1) in the period (2001-2010) of 3,1 $\mu \mathrm{g} / 1$ indicates that this toxic metal derived from natural origin and is located within the expected quantities of class I-II. Its concentration in any particular month or in isolated cases does not exceed the threshold of alarm for water quality prescribed by the Regulation on categorization and classification of rivers in R. Macedonia. The precipitation of dissolved copper increases the sediment downstream along so that its concentration in the water at the measuring point Demir Kapija (point 2) annually $(2,6 \mu \mathrm{g} / \mathrm{l})$ are smaller than those in Nogaevci during the same period. The whole picture indicates extremely minimal anthropogenic impact on the quality of Vardar Tikves (tab. 1, 2; fig. 2, 3). The results of the above table does not met preliminary assumptions about the quality of Bregalnica in Ubogo (point 3), which examined the period maintained quality class I-II. Namely, expectations were quite reasonable, the left tributary of age to enter higher amounts copper recipient, knowing with certainty that in her basin (Lakavica River) is permissible quantity sustain copper from mine wastewater Mine. The results of the quality of the Crna Reka (point 4) of the measuring point Palikura (2001-2010) annually slightly elevated relative to those of Bregalnica's Ubogo or Vardar near Demir Kapija, but refer to the class I-II. But the fact itself proves that watercourse carries increased amounts of dissolved copper from the upper sections (Pelagonija) or tributaries coming from Kozufvolcanic area. In summary it can be concluded that the flow of Bregalnica and Crna Reka are apparently not charging over the Vardar Tikves valley with toxic metals like copper (tab. 3 , 4; fig. 4, 5). 


\section{CONCLUSION}

In this paper were studied the waters of the river Vardar and Tikves's major tributaries: Bregalnica and Crna Reka in the period from 2001-2010. The waters of Vardar were monitored from two measuring points: at the entrance to the valley near the village Nogaevci (point 1, fig. 1) and downstream near Demir Kapija (point 2, fig. 1). The waters of the Crna Reka and Bregalnica were monitored before their confluence (point 3, 4; fig. 1). The assessment of the water quality was based on 8 heavy metals as a criterion for quality, which have a significant impact on agricultural production, irrigation conditions. Regarding the presence of heavy metals in the River Vardar string section examined, it was determined deterioration based on only one indicator, lead $(\mathrm{Pb})$, while compared to other indicators marked improvement of water quality. Most indicators express concentrations within the class I-II of the two measuring points on the river Vardar, except cadmium which is present in concentrations class III-IV, also from the two measuring points. Compared with the quality of river Vardar at both measuring points before and after the entry of its largest tributaries, their impact on the recipient can be seen only with some of the heavy metals. Namely, Bregalnica is most burdened with lead and it is the largest source of pollution of Vardar whose lead concentration in downstream recipient is growing, and the water quality is deteriorating. Increased concentrations relative to the recipient Bregalnicaare shown in terms of manganese. Crna Reka demonstrates conclusively highest water quality in terms of heavy metals compared to Bregalnica and Vardar from the two measuring points. The only pressure on the recipient are shown toward nickel, which measuring point in Palikura has the highest multi concentration.

\section{REFERENCES}

[1] Stojmilov A. Geography of Macedonia. 2011, Skopje, University of Touarism and Management pp. 567 (in Macedonian)

[2] Popov I. S., Stafilov T., Šajn R., Tănăselia C., Bačeva K. Applying of Factor Analyses for Determination of Trace Elements Distribution in Water from River Vardar and Its Tributaries, Macedonia/Greece. 2014, The Scientific World Journal Volume (2014), Article ID 809253, 11 pageshttp://dx.doi.org/10.1155/2014/809253

[3] Pavlov K. The Influence of Natural and Antropogenal Factors on Water Pollution in Tikveš Basin (PhD thesis). 2011, Skopje, Faculty of Natural Sciences and Mathematics pp. 424 (in Macedonian)

[4] Karri-Matti V. Direct and indirect effects of iron on river ecosystems. 1995, Helsinki, Ann. Zool. Fennici 32: 317-329

[5] Rowe, D.R., Abdel-Mazid I.M. Handbook of Wastewater Reclamation and Reuse. 1995, CRC Press, Inc. 550 pp

[6] Ramani S., Bojkovska R., Pavlov K. Environmental Assessment of Water quality of the River Strumica During the last ten years with Overview on 2008. 2010, Ohrid, Balwoise Proceedings

[7] Pavlov K. 2015

[8] Pavlov K., Bačeva K., Stafilov T., Vasileski D., Toševska S. Assessment of Toxic Metal Pollution in Some Rivers in the Tikveš Basin, Republic of Macedonia. 2012, International Journal of Environmental Protection Dec. 2012, Vol. 2 Iss. 12, PP. 9-16 
[9] Pavlov K., Pavlovski G., Radevski I. River Water Pollution with Heavy Metals in the Hilly and Mountain areas in the Tikvesh Basin. 2013, Skopje, Proceedings of Scientific Conference (in Macedonian with English summary) 